\title{
Travelogue for Children: Bhakti Mathur's Amma, Take Me to The Golden Temple (2017)
}

\author{
Raj Gaurav Verma \\ Assistant Professor of English, University of Lucknow. ORCID: oooo-ooo3-1819-3376. Email: \\ ajgauravias@gmail.com
}

\begin{abstract}
This paper argues that travel writing not only neglected women (at least in its initial stages) but also children in its critical idiom. One of the recent additions to travel writing can be seen in Bhakti Mathur's Amma Take Me Series, which sets a landmark in adding the gendered and the childist perspective in travel writing. The 'Amma Take Me' Series: “Come Explore the Places Where We Worship” is published under Puffin Books by Penguin Random House India. This series introduces readers to the history of the major Indian faiths through their important places of worship like Shirdi, Golden Temple, Tirupati and the Dargah of Salim Chishti. So far there are four books in the series. They are written as travelogues of a mother and her two young children and are designed for children between eight to twelve years. Mathur uses mythology, tradition and history associated with these places to unfold their story as they travel. While children's literature shows the pattern of 'Home' and 'Away'; travel writing is marked by an outside trip or journey. Amma Take Me Series conforms to the pattern of both the genres in its treatment of "outsiderness." This series is different as it allows the children (in the text and the child-reader) an access to the outside world, especially to places of worship, guided by their mother who is both the narrator and a source of information. This adds another aspect to travel writing which is about learning one's own culture through spaces of historical and religious significance. The 'outsiderness' is connected to a 'sense of identity' and 'extension of self' to these places which results in "spatial-socialization" for children. This paper attempts to read Amma, Take Me to the Golden Temple (2017) in the context of gender and children's literature theory and criticism and the way they develop this socio-spatial and historical-personal relationship through their narrative. The study asserts the "transcendental nature" of travel writing and the ability of pilgrimnarratives in particular, to offer solutions to the problems we face today.
\end{abstract}

Keywords: travel writing, pilgrimage, children's literature

This paper studies Bhakti Mathur's Amma, Take Me to The Golden Temple as an introduction to a hybrid genre that is religious travel. 'Amma Take Me' Series: "Come Explore the Places Where We Worship" is a refreshing addition to travel writing which transcends the normative idea of travel. The author has intertwined various genres of popular narratives like children's literature, travel writing, and picture book. Her work may be considered as a continuum of travel accounts of visits to holy lands, of the world in general and India in particular.

Travelogues form a considerable volume of literature from the Indian subcontinent, Here, journeys were undertaken by Indian men and women because of migration, trade, religion (pilgrimage and to escape from communal violence), diplomacy, education, science and for the purpose of creating travel accounts (Bhattacharji, 2016, p. 125). One of the earliest forms of travel

(C) AesthetixMS 2020. This Open Access article is published under a Creative Commons Attribution Non-Commercial 4.o International License (http://creativecommons.org/licenses/by-nc/4.o/), which permits non-commercial re-use, distribution, and reproduction in any medium, provided the original work is properly cited. For citation use the DOI. For commercial re-use, please contact editor@rupkatha.com. 
was religious travel, pilgrimages to distant lands through dangerous terrain. Texts from the ancient periods convey several accounts of such journeys. The mythological texts of Hindus, the Puranas and Upapuranas, include sthalamahatmyas gave directions to pilgrims and priests in reaching sacred places. The Kasimahatmya gives the description of Kashi and the Keralamahatmya narrates the story of the formation of Kerala. Even in the middle ages pilgrimage remained "the dominant medieval framework for long-distance, non-utilitarian travel" (Sherman, 2002, p. 24). Buddha and Mahavira are known for their wandering zeal in spreading their knowledge. Later on the visits of Mahendra and Sanghamitra in the times of Ashoka are known for spreading Buddhism in South- East Asia.

The reading of Amma, Take Me to The Golden Temple (2017) marks a resurgence of Indian travel writing that connects while moving. The text evokes the notion of "transcendental travelling" which occurs in most travel writings. This concept of transcendental travel writing posits the idea that by its nature a travelogue is able to transcend at several levels. Transcendence, in this context implies the quality of travel writing to sublimate, uplift, and move beyond the perceived boundaries of genre, nation, culture, and social-constructs. The relationship of travel writing with other disciplines of politics, anthropology, history, economics, geography, ethnography, linguistics and literature is gradually gaining credence. This genre is now studied in the larger framework of interdisciplinarity, intersecionality, cross-cultural approaches and spatiotemporal narrative. The result of such exchanges, experimentation and attempts, is the development of a hybrid genre of travel writing (Hoggan, 1998; Bassnett, 2002). Amma, Take Me to The Golden Temple is one such attempt by Mathur where she has intertwined various genres of popular narratives like children's literature, travel writing, and picture book.

Travel writing transcends the national and regional boundaries. A traveller can be seen moving "in-between," in the words of Homi K. Bhabha, not only between two places but also two cultures and continually evoking and erasing "the totalising boundaries of the nation state" (Bhabha, 1994,p. 149). This generates a number of equations and relationships between the idea of 'home' and 'abroad,' 'self and the other,' nation and identity, place and personality, from colonial legacy to post-colonial existence. This results in transculturation, a "phenomenon of the contact zone" (Pratt, 2008). Indian Travel Writing reveals similar concerns dealing with the idea of 'home' to 'self' and also to the other, with travels extending from colonial period to the West to countries in East, and the journeys of pilgrimages within the countries and to the Himalayas (Mandal, 2010). Golden Temple is one such holy place which is visited by tourists and pilgrims from all over the world. The fact of travelogues transcending the regional boundaries occurs in Mathur's text in the perpetual movements of the Sikh Gurus. At the same time travelogue as a text can transcend space or region just like the travellers crossing their national boundaries.

Bill Aitken (2008) notes that pilgrims have contributed numerous tributes to the glory of the Himalayas in vernacular narratives. Pilgrims can be seen as the ancestors of modern tourists. The writings that were a part of pilgrimage or were related to them remain influential because their narrative can easily be mixed with other literary genres. In fact, pilgrimage has not only influenced but transformed the idea of tourism in contemporary times (Hulme, \& Youngs, 2002,pp. 2-3; Donald, 1980; Buzard, 1993).

Again, travel writing may convey an experience of transcending the physical or material world which is the motivation in case of pilgrims and "searching for a sense of identity, seeking some meaning in an otherwise inexplicable event, craving miracles and cures" (Reader, 1993, p. 220). Pilgrimage is "connected with the state of the soul... the search for inspiration" and "need to participate in history" (Sztachelska, 2010, p.5). "Pilgrimage was a theological idea and a cultural 
phenomenon - but above all it was a religious institution, a devotional practice" (Zacher, 1976, p. 4). It is seen as "re-enacting the metaphysics of the travelling human soul in motion towards enlightenment" (Chaudhuri, 2019, p. 161); as an attempt to observe "experience and curiosity towards other lifeways" (Buzard, 1993); as a "progress toward a spiritual or heavenly goal" (Olsson, 1979). Consequently, pilgrimage has become an enormous activity occurring almost in all the parts of India. From Amarnath and Vaishno Devi in Jammu \& Kashmir to Tirupati in Andhra Pradesh, from Dwarka in Gujarat to Kamakhya Temple in Assam, Ayodhya, Benaras, Mathura, Chitrakoot, and Shirdi, holy places are filled with pilgrims throughout the year. Shobhna Bhattacharji (2016) also mentions the presence of a "special sort of Hindu pilgrim literature" in the form of "small, cheap pamphlets advising pilgrims on what to wear and carry, and prescribing ritual and prayer for every stage on pilgrimage" (p. 134).

Bhakti Mathur's Amma, Take Me to the Golden Temple is a travelogue, and a pilgrimage since it is about visiting the holy Golden Temple at Amritsar. The reader is taken by surprise looking at the cover of the book where the subtitle, Amma, Take Me To is on the top of the title The Golden Temple. This appears as an inverted case where a subtitle is actually occurs before the title. It can be a mere coincidence, or a grammatical or stylistic necessity, but it is important to note that being a children's book the Golden Temple cannot be introduced or visited without an adult, the adult here being Amma, the mother. Title in itself indicates the generic attempt of socializing through the mother and enculturation (Herskovits, 1948) through the spatial and historical narrative of the Golden Temple.

It is important to remember that travel writings transcend the social constructs vis-à-vis representation of women, children, and muted sections in the progression of the narrative. Mary Louise Pratt (2008) in the context of European women travellers, observes that the trope available for men in their travels "the monarch-of-all-I-survey," characterized by "the masculine heroic discourse of discovery" was not readily available for women (p. 209). Instead of using "sexual metaphors" and "the language of penetration, conquest and domination" so commonly employed by men, the women travel narratives combined "the excitement of unpredictable exploration with the pleasure of knowing where one is" (McEwan, 2000, Ch. 3). Susan Bassnett (2002) notes that in the patriarchal society women were mostly confined to their homes and yet "women did travel in all kinds of roles - as wives, sisters, daughters of missionaries, diplomats or envoys, as scientists or naturalists, as explorers..." as individuals "in search of the unexpected, or of leisure or instruction, alone or accompanied, for personal or professional reasons" (p. 231). Through their travels they could break free from the shackles of society and find escape from the "the constraints of domesticity" (p. 233-234). Thus, Carl Thompson (2011) remarks that though the genre of travel writing gave a superficial appearance of being strongly related to men in nineteenth and twentieth centuries, contrastingly, women have also emerged as prolific writers of travelogue (p. 3). Travel writing thus transcended the "the singularity of dominant culture" making itself multifocal and reflected "the role of women in adjusting perspectives" (Bassnett, 2002, p. 231).

Theorists and critics of travel writings note that pilgrimage was one sort of travel which was common to all religious traditions and admissible for women travellers in the colonial and patriarchal structures (Nenzi, 2016, p. 217) and enabled them "to travel independently of men, either individually or in female-only groups" (Morrison, 2000). Nevertheless, studies in travel writings expose the peripheral treatment of women travellers and their writings (Bhattacharji, 2008, p. ix). This is because of the difference between male and female travellers: firstly, as "women were constrained by feminine code of conduct" they "are more likely to be self-effacing, developing strategies of accommodation rather than confronting and emphasizing their 
femininity." Another major difference is between "scientific and professional tone of male" and the "more self-conscious tone of women travellers" (Alison Blunt, 1994, p.36). This also holds true for the women travel writers in India.

Amma, Take Me to the Golden Temple becomes an exception in the line of travel writing due to its approach. Bhakti Mathur's narrative can be seen, as Dúnlaith Bird (2016) writes, a "travel with both a gender and an agenda, experimenting with narratorial perspectives" (p. 43). The book opens with Amma (whose name is not mentioned) and her children Shiv and Veer. She is on a pilgrimage. Here Amma is shown moving with her children but there is no reference to a father. In conventional society father and mother are stereotyped in their roles towards children. It is the father who is attributed the role of sharing public and worldly knowledge, whereas mother shoulders with the responsibility of inculcating domestic manners and etiquettes. Amma, in this text, does both. She is an informed traveller and unfolds to her children the history and legends of the Golden Temple through her stories, and at the same time directing Shiv and Veer how to behave or to speak in a proper manner.

In addition, part of the skepticism towards travel writing arises from the "capacity of travel writers to distort the truth - amplifying their observations, claiming credit for what they never witnessed or inventing fabulous narratives wholesale from the imagination rather than experience" (Carey, 2016, p. 3). Amma, Take Me to the Golden Temple averts this loophole, firstly, by Mathur's attempt at providing a "Selected Bibliography" where she gives details of all the books she has consulted on Sikh history and religion. Apart from that, the book includes in its appendages the description of "The Ten Gurus," "A Historical Timeline of the Golden Temple," "Interesting Facts," and a "Glossary" indicating the research and study that the author has undertaken. Also, the narrative proceeds with meticulous representations through the illustrations made by Priyankar Gupta, whom Mathur acknowledges "for giving colours to my words and bringing the story to life" (p. 65).

The magnificence of the Golden Temple is illustrated when Amma, Shiv and Veer enter the arched gateway leading to the temple complex. The opening page has a metaphoric appeal of 'entering' as the text is wrapped within the picture of the gateway. Entering the text, the readers who have visited the Golden Temple would experience the same sensation of entering the Temple through the shallow pool of cold water "meant to cleanse one's feet before entering the holy grounds beyond" (Mathur, 2017, p.1). The overwhelming presence of the Golden Temple is felt by Amma, Shiv and Veer:

Straight ahead, in the middle of a large lake, brilliantly lit and bright against the background of the dark sky, stood an elegant dome square structure seemingly carved out of solid gold. There is was. The Golden Temple of Amritsar. (Mathur, 2017, p. 2)

Ian Reader (2015) writes in this regard that as a concept and practice, pilgrimage meant leaving home, visiting and performing the "acts of veneration at places where holy figures from their tradition had been, where significant events associated with them had occurred, and where their spiritual presence could, it was believed, still be felt" (p. 20). Therefore, if travelling in a foreign land can destabilize understanding about the "consolidation of stable unitary identities of nation, class, sexuality or gender, and suggest forms of Selfhood that evade such consolidations" (Grewal, 1996, p. 3); travelling to holy places meant to remain connected to the roots (Nenzi, 2016, p. 224) and reinstate the sense of identity within the broader domain of culture, geography, history, religion and ethnography. Thus, a pilgrimage emphasizes the sense of identity derived from connection with the culture and place of visit. Mathur's choice picks up "the Sikh tradition" which "has its network of pilgrimage places, including the Golden Temple in Amritsar, Sikhism's 
holiest site and main pilgrimage" (Reader, 2015, p. 6). She creates a journey through history within her narrative explaining about all the ten great Sikh Gurus. Since "pilgrimages, ..., traditionally involve a renovation of faith" (Thompson, 2011, P. 106), so Amma, Take Me to the Golden Temple generates a sense of historical identification and brings back the teachings of the Gurus, their struggle and their relevance to our times.

Travel writing and children's literature form a part of popular literature. Despite being two distinct genres with their own approaches and audiences, they share some common traits. The very basic thread in both travel writing and children's literature is "home" and "away." While in travelogues this trope is seen in the context of home and abroad or visiting a foreign or different place (Mandal 2010; Edwards \& Graulund, 2011, p.7; Thompson, 2011, p. 5, 16; Knowles, 2014, p. 12); in children's literature this emerges as an intermediary narrative space between home and the outside world (Nodelman \& Reimer, 2003; Nodelman, 2008). Both these genres rely heavily upon the difference that is generated in contrasting images of home and away/abroad. The second important aspect shared by children's literature and travel writing is "a sense of curiosity, excitement, adventure, and even moral fervor" (Pratt, 2008, p. 3). The third aspect of children's literature and travel writing relates to their innate capacity to act like a bildungsroman because of their "twinnings of outer and inner journeys" (Cooke, 2016, p. 20), where "some inner journey, some adventure in the self; is the real point" (Rushdie 225) and where travelling "shows the human condition with its longings and dreams of unknown adventures of the body, mind and soul" (Sztachelska, 2010, p. 6). Moreover, like for women, travel writing carried an ironical stand for children. All adventures are brought back to the home for children but no work represented one on real travelling. Perhaps this is because travelling involves the idea of a lonely traveller, as William Hazlitt proposes in his essay "On Going on a Journey," which could not be but a masculine one. Absence of children from this form of writing was thus not surprising. This also meant the under-representation of children in the critical process of travel writing.

Also, childist criticism means giving consideration to the fact that "children read distinctively from adults" and like-wise their perceptions will be different (Hunt, 2001, p. 263). Karen Coats (2011) suggests that it is important for children "to see themselves in the book" in order to validate and affirm their particular identity structures. "Black girls need stories about black girls, gay boys need to read about gay boys...so that they do not have to adopt alienating and oppressive subject positions or feel invisible as they read" (p. 111). The same holds true for the representation of minorities and their places of worship. Studies show that "pilgrims in different places and times seldom think of themselves as 'just' pilgrims or even as religious travelers; they account for all their identities, interests and idiosyncrasies in narratives" (Nenzi, 2016, p. 225). Pilgrimage to the Golden Temple provides an opportunity not only to represent a mother traveller but also her children.

Amma, Take Me to the Golden Temple is a travelogue not only in a generic sense but also in the narratorial, metaphoric and spatial sense. Mathur admits in her acknowledgements that "Writing this book has been quite the journey." Writing, just like reading, has an intrinsic element of journeying. This journeying is done not alone but with her children and thus it has to proceed in manner not narrative but dialogic. Pilgrimage often acquires dialogic, holistic and even metaphorical character (Nenzi, 2016, p. 225). Likewise, Bassnett (2002) notes a change in stylistic techniques in the development of travel narratives in the twentieth century as there can be observed an increased use of dialogue blurring the boundary between travelogue and fiction. There is an involvement of the protagonist with other characters through her conversations and 
"the reader is expected to believe that such conversations... are recorded rather than invented" (p. 231).

Travel writing transcends the temporal in connecting past, present and anticipation of future prospects. Mathur's text elucidates the fact of pilgrimage as a diachronic transmission of culture through space. Starting with a reference to "a-40o- year- old Guru" the text talks about a pilgrimage taken in recent times, that helps to connect with one's heritage. The Golden Temple is not only known for the pilgrims visiting in contemporary times but it also has a history of the Gurus, saints, and other pilgrims visiting since its establishment. As Smethurst (2009) writes, the sense of time and "mobility is spatialised and synchronised, so the travel writer is able to present reality as an orderly representation" (p. 2). It presents a diachronic exchange between history and present, parents and children, memory and lived experience. As Amma, Shiv and Veer pass through Akal Takht, Darshan Deori, and visit inside the Golden Temple, and then the Lachi Ber, Ber Baba Budha, and Dukh Bhanjani Beri, the three great tresses in the Golden Temple, and finally return to the Akal Takht, Amma narrates the stories and incidents related to them through her memory and experience.

Mathur uses meta-narrative technique to connect one incident with another, one story with another. Amma tells the story of Nanak. His childhood was not very remarkable. Though he was very bright as a student, he showed no desire or ambition to take up a job. He loved to wander in the nearby forests and would talk to fakirs and sadhus. Once his father sent him to the market to make the best bargain and bring the goods. Nanak goes to the market makes the best bargain and bring those goods, but on his way he meets a troop of hungry fakirs. He lights a hearth, cooks for them and feeds them. When he returns empty handed to his home his father gets furious. Nanak refuses to eat anything but his mother very sweetly comes to him and says: "You found such happiness in feeding those hungry men...Won't you share that happiness with me? Won't you let me feed just one hungry boy?” (Mathur, 2017, pp. 13-16). Mathur actually evokes the archetypal mother figure by referring to Nanak's life and by making its presence felt in her titles. Nanak then started his sojourns as a spiritual preacher. It is said that Nanak started his journey by visiting the place now called as Amritsar. He was charmed by the beauty of the lake surrounded by thick groves. It was at this spot where Guru Arjan Dev, later built Harmandar Sahib. Emphasizing on his teachings of equality Guru Nanak started the tradition of langar or community kitchen.

As the narrative proceeds Amma tells about the brutal torture and death of Guru Arjan Dev at the hands of the proselytizing Emperor. Guru Hargobind became the next guru and realized that "they could no longer remain just the peaceful men of God" and they have to prepare themselves to face further attacks. He initiated the militia Sikhism by organizing an army and announcing his followers to wear two swords at waist: one symbolizing the godliness of Sikhs, the other marking them as soldiers. Later on when Guru Tegh Bahadur was killed by the Mughal Emperor Aurangzeb, Guru Gobind Rai formed the Khalsa, "Pure Ones." He chose Panj Pyare, the five men who were ready to sacrifice their life for their Guru. He gave a new surname to his family of Khalsa, Singh. He changed his name to Guru Gobind Singh and decided on the Panj Kakars or the five Ks (Kesh, Kangha, Kirpan, Kada, and Kachha). He proclaimed:

You are the sons of Nanak...You will promise to follow his teachings. You will love people as people, making no distinction among them. You will fight injustice, but your actions will only be to protect yourself and not born out of hatred. You are both saints and soldiers. (Mathur, 2017, p. 57) 
This completes Amma's historical story-telling about the development of spiritual Sikhism starting from Guru Nanak into combative Sikhism of Guru Gobind Singh.

The most basic kinds of social interaction seen from a developmental point of view are the "the sharing of memories between parent and child" (Campbell, 1995, p. 1). Amma's stories and the spatial reality project a movement to and fro in time, between past and present. Thus her narrative is marked by, what Alison Blunt (1994) calls, "spatialization of time" and "temporalization of space" (p. 17). The way Amma unfolds the story about the major structures, trees, and the Sikh Gurus, she actually transforms the landscape in "a kind of text" (Mitchell, 2000, p. 122). The visit to the Golden Temple is not simply an aesthetic or adventurous experience but also how as a landscape it acts as a "source of meaning and as a form of social regulation" and as a "cultural space" (Mitchell, 2000, p. xix-xxi). Tony Watkins (1999) also suggests the "power of some landscape to be read as national geography" (p. 68). The Golden Temple in that way not only forms the part of the great Sikh history and culture but also the national cultural heritage of India.

Pilgrimage, in case of children, allows an individual to adopt culture by the process of enculturation and assimilation. Margaret Mead attempted to show that an individual adopts not only the material aspects of culture but also the "non-material aspects of culture, such as religion, tradition, custom, beliefs, norms, values, ideals" (In Upadhyay and Pandey, 1997, p. 309). The visit to the Golden temple can be read as an attempt at educating, transmitting knowledge and cultural memory, and socializing through the "the layout and use of architectural space" as a pedagogical device (Peatross \& Peponis 1995).Therefore, if travelling abroad resulted in transculturation; travelling in home fructified in enculturation and socialization through space.

Amma, Take Me to the Golden Temple, while conveying the history of the great Sikh Gurus also develops a sense of time in the children. Lisa Sainsbury (2005) opines that it is difficult for children to understand the abstract notion of time. The relationship of children with time is "complicated by their restricted experience of it - particularly of time past." The "acquisition of time sense is actually part of the socialization process, working alongside such things as the learning of language skills or moral values. Past, present and future are cultural concepts that change in accordance with social development" (p. 157). It is also to be noted that "children organize the world spatially, before they can do it temporally, and that the acquisition of time sense during the concrete-operational period requires that they decenter from their dependence on a spatially concrete understanding of the world" (Appleyard, 1994, p. 72). This time sense is well brought out in Amma, Take Me to the Golden Temple with illustrations which vary with time in depiction of Guru Nanak as a child and as an adult, leaping to the times of Raja Ranjit Singh, and once again moving back to Guru Arjan Dev, and Guru Gobind Singh; but at the same time remaining closely associated spatially to the portrayal of the Golden Temple. The time shift in the narrative "offers the reader a movement between the familiar and the unknown" (Thompson, 2011): familiar, which is the present, the place of visit; unfamiliar, which is past, the history associated with the place. In fact the visit to the Golden Temple is set in the morning hours "before the sun woke up" (p. 1) and most of the pictures illustrated are bright and magnificent projection of various views of the temple in bright daylight. The book ends with "the Akal Takht behind them and Harmandar Sahib glowing in front, Amma, Shiv and Veer started walking towards the langar hall" (Mathur, 2017, p. 61). This travelogue creates and revives the memory which "might be inscribed with the past, but it also has hand in shaping action, response and identity in the present and for the future" (Sainsbury, 2005, p. 171). In this sense Mathur's work 
shows how travel writing is "linked with the construction of identity" (Mandal, 2010) for both the traveller and the reader.

Travel writing transcends the narrow human individual existence. This is something that is different from other travelogues and makes Amma, Take Me to: The Golden Temple particularly interesting. The text offers the redemptive mantra that "Guru Nanak also believed that true worship of God is not just in remembering Him and being true to Him at all times. It is also, sharing what we have with others and helping those in need" (Mathur, 2017, p. 18). The bonding that he and other Gurus had shared with trees is not only admirable but also exemplary as those trees are worshipped within the precincts of the Golden Temple.

The children of today are the citizens of tomorrow who have to deal with managing the home, nation and economy. They would be the heirs to a "good earth" or a dying planet. It is they who may have to face the consequences of the "Anthropocene" and would have to succumb to their impoverished resources or take on the challenge and retrieve nature. One possible solution to the anthropocene predicament proposed by Haraway (2016) is "make kin, not babies" (p. 312). This was precisely what was taught by Nanak and remains eternally inscribed in the holy Guru Granth Sahib. That social inequality would lead to ecological imbalance, sheer individualism will lead to complacent and self-justifying selfishness, accumulation of capital will lead to global disaster, was made apparent by the Sikh Gurus. Thus as a travelogue Amma, Take Me to: The Golden Temple succeeds in creating adventure out of history and religion; offers gender/genrebending narrative; establishes the Golden Temple as a symbol of community service, love for nature and fellow human beings, an ever expanding sense of self and a solution to the current anthropocenic challenge.

\section{References}

Aitken, B. (2008). Travel Writing about the Himalaya: The Interplay of Religion, Sport, Trade and Politics. In Bhattacharji, S. (Ed.)Travel Writing in India (pp. 11-27). New Delhi: Sahitya Akademi.

Appleyard, J. A. (1994). Becoming a Reader: The Experience of Fiction from Childhood to Adulthood. Cambridge University Press.

Bassnett, S. (2002). Travel Writing and Gender. In P. Hulme \& T. Youngs (Eds.), The Cambridge Companion to Travel Writing (pp. 17-36). Cambridge University Press.

Bhabha, H. (1994). The Location of Culture. Routledge.

Bhattacharji, S. (Ed.)(2008). Introduction. Travel Writing in India (pp. vii-x). New Delhi: Sahitya Akademi.

Bhattacharji, S. (2016). Indian Travel Writing. In Thompson, C. (Ed.). The Routledge Companion to Travel Writing (pp. 125-138). Routledge.

Bird, D. (2016). Travel Writing and Gender. In Thompson, C. (Ed.), The Routledge Companion to Travel Writing (35-45). Routledge.

Blunt, A. (1994). Travel, Gender, and Imperialism: Mary Kingsley and West Africa. New York: The Guilford Press.

Buzard, J. (1993). The Beaten Track: European Tourism, Literature, and the Ways to 'Culture,' $1800-1918$. Oxford: Clarendon Press.

Campbell, J. (1995). Past, Space and Self. Cambridge, Mass.: MIT Press. 
Carey, D. (2016). Truth, Lies and Travel Writing. In Thompson, C. (Ed.), The Routledge Companion to Travel Writing (pp. 3-14). Routledge.

Chaudhuri, S. (2019). Indian Travel Writing. In Nandini Das and Tim Youngs (Eds.),

The Cambridge History of Travel Writing pp 159-174. Cambridge University Press.

Coats, K. (2011). Identity. In P. Nel\& L. Paul (Eds.), Keywords for Children's Literature (pp. 109-112). New York: New York University Press.

Cooke, Simon. (2016). Inner Journeys: Travel Writing as Life Writing. In Carl Thompson (Ed.), The Routledge Companion to Travel Writing (15-24). Routledge.

Edwards, J. D., \& Graulund, R. (Eds.). (2011). Introduction: Reading Postcolonial Travel Writing. Postcolonial Travel Writing: Critical Explorations (pp. 1-16). Palgrave Macmillan.

Grewal, I. (1996). Home and Harem: Nation, Gender, Empire, and the Cultures of Travel. Durham: Duke University Press.

Haraway, D. J. (2016). Staying with the Trouble: Making Kin in the Chthulucene. Durham: Duke University Press.

Hazlitt, Williams. (2013). On Going on a Journey. In Selected Essay: An Anthology of English Essays for Undergraduate Students. Orient BlackSwan.

Herskovits, M. (1948). Man and His Works. New York: Knopf.

Hulme, P., \&Youngs, T. (Eds.). (2002). The Cambridge Companion to Travel Writing. Cambridge University Press.

Hunt, P. (2001). Children's Literature: Blackwell Guides to Literature. Oxford/Malden, Mass: Blackwell Publishers Ltd.

Knowles, Sam. (2014). Travel Writing and the Transnational Author. Palgrave Macmillan.

Mandal, S. (Ed.) (2010). Indian Travel Narratives. Jaipur \& Delhi: Rawat Publications.

Mathur, B. (2017). Amma, Take Me to The Golden Temple (Priyankar Gupta, lllus.). Penguin Random House India (Puffin Books).

McEwan, Cheryl. (20oo). Gender, Geography and Empire: Victorian Women Travellers in West Africa. UK: Ashgate Publishing.

Mitchell, D. (2000). Cultural Geography: A Critical Introduction. Oxford/Malden, Mass.:Blackwell.

Morrison, Susan S. (2000). Women Pilgrims in Late Medieval England. Routledge.

Nenzi, L. Pilgrims. In Carl Thompson (Ed.), The Routledge Companion to Travel Writing (217-226). Routledge.

Nodelman, P. (2008). The Hidden Adult: Defining Children's Literature. Baltimore: The John Hopkins University Press.

Olsson, K. (1979). Modern Philology, 77(2), 196-200. Retrieved April 6, 2020, from www.jstor.org/stable/437509

Peatross, F., \& Peponis, J. (1995). Space, Education, and Socialization. Journal of Architectural and Planning Research, 12(4), 366-385. Retrieved March 30, 2020, from www.jstor.org/stable/43029178

Phillips, R. Decolonizing Travel: James/Jan Morris’s Geographies. (2011). In Justin D.

Edwards \& Rune Graulund, (Eds.), Postcolonial Travel Writing: Critical Explorations (pp. 1-16). Palgrave Macmillan.

Pratt, M. L. (2008). Imperial Eyes: Travel Writing and Transculturation. Second Edition. Routledge. 
Reader, I. (2015). Pilgrimage: A Very Short Introduction. Oxford University Press.

Reader, I. (1993). Conclusions. In I. Reader \& T. Walter (Eds.), Pilgrimage in Popular Culture. (pp. 220-239). Macmillan.

Rubies, J. P. (2002). Travel writing and Ethnography. In P. Hulme and T. Youngs (Eds.), The Cambridge Companion to Travel Writing (pp. 17-36). Cambridge University Press.

Rushdie, S. (2010). On Adventure. Imaginary Homelands: Essays and Criticism 1981-1991 (pp 222-225). New York: Vintage Books.

Sainsbury, L. (2005). Chronotopes and Heritage: Time and Memory in Contemporary

Children's Literature. In Kimberley Reynolds (Ed.), Modern Children's Literature: An Introduction (pp. 156172). London: Palgrave Macmillan.

Sherman, W. H. (2002). Stirrings and Searchings (1500-1720). In P. Hulme \& T. Youngs (Eds.), The Cambridge Companion to Travel Writing (pp. 17-36). Cambridge: Cambridge University Press.

Smethurst, P. (2009). Introduction. In Julia Kuehn and Paul Smethurst (Eds.), Travel Writing, Form and Empire: The Poetics and Politics of Mobility (pp. 1- 18). UK: Routledge.

Sztachelska, J. (2010). Introduction. In G. Moroz \& Sztachelska, J. (Eds.), Metamorphoses of Travel Writing: Across Theories, Genres, Centuries and Literary Traditions (pp. 1-7).Newcastle Upon Tyne, UK: Cambridge Scholars Publishing.

Thompson, C. (2011). Travel Writing. Routledge.

Upadhyay, V.S., \& Pandey, G. (1997). History of Anthropological Thought. New Delhi: Concept Publishing Company.

Watkins, T. (1999). Space, History and Culture: The Setting of Children's Literature.

Peter Hunt (Ed.), Understanding Children's Fiction (pp. 50-72). Routledge.

Zacher, C. K. (1976). Curiosity and Pilgrimage: The Literature of Discovery in Fourteenth-Century England. Baltimore: The Johns Hopkins University Press.

Raj Gaurav Verma is an Assistant Professor in the Department of English and Modern European Languages, University of Lucknow. Previously he has worked as an Assistant Professor in the Department of English, Central University of Jammu. He has worked on children's literature in English in India. His areas of specialization include Modern/Postmodern Literature, Indian Writing in English, Literature of the diaspora and Literary Theory and Criticism. 